\title{
Response of Tibetan Wild Barley Genotypes to Drought Stress and Identification of Quantitative Trait Loci by Genome-Wide Association Analysis
}

\author{
Mian Zhang ${ }^{1,2}$, Man-Man Fu ${ }^{1}$, Cheng-Wei Qiu ${ }^{1}$, Fangbin Cao ${ }^{1}$, Zhong-Hua Chen ${ }^{4}$, \\ Guoping Zhang ${ }^{1}$ and Feibo $W^{1,3, *}$ \\ 1 Department of Agronomy, College of Agriculture and Biotechnology, Zijingang Campus, \\ Zhejiang University, Hangzhou 310058, China; zhangmian7285@sxu.edu.cn (M.Z.); \\ sunshineabigail@163.com (M.-M.F.); 3130100260@zju.edu.cn (C.-W.Q.); caofangbin@zju.edu.cn (F.C.); \\ zhanggp@zju.edu.cn (G.Z.) \\ 2 Institute of Applied Biology, Shanxi University, Taiyuan 030006, China \\ 3 Jiangsu Co-Innovation Center for Modern Production Technology of Grain Crops, Yangzhou University, \\ Yangzhou 225009, China \\ 4 School of Science and Health, Hawkesbury Campus, University of Western Sydney, Penrith, NSW 2751, \\ Australia; z.chen@uws.edu.au \\ * Correspondence: wufeibo@zju.edu.cn
}

Received: 9 January 2019; Accepted: 7 February 2019; Published: 12 February 2019

\begin{abstract}
Tibetan wild barley has been identified to show large genetic variation and stress tolerance. A genome-wide association (GWA) analysis was performed to detect quantitative trait loci (QTLs) for drought tolerance using 777 Diversity Array Technology (DArT) markers and morphological and physiological traits of 166 Tibetan wild barley accessions in both hydroponic and pot experiments. Large genotypic variation for these traits was found; and population structure and kinship analysis identified three subpopulations among these barley genotypes. The average LD (linkage disequilibrium) decay distance was $5.16 \mathrm{cM}$, with the minimum on $6 \mathrm{H}(0.03 \mathrm{cM})$ and the maximum on $4 \mathrm{H}(23.48 \mathrm{cM})$. A total of 91 DArT markers were identified to be associated with drought tolerance-related traits, with 33, 26, 16, 1, 3, and 12 associations for morphological traits, $\mathrm{H}^{+} \mathrm{K}^{+}$-ATPase activity, antioxidant enzyme activities, malondialdehyde (MDA) content, soluble protein content, and potassium concentration, respectively. Furthermore, 7 and 24 putative candidate genes were identified based on the reference Meta-QTL map and by searching the Barleymap. The present study implicated that Tibetan annual wild barley from Qinghai-Tibet Plateau is rich in genetic variation for drought stress. The QTLs detected by genome-wide association analysis could be used in marker-assisting breeding for drought-tolerant barley genotypes and provide useful information for discovery and functional analysis of key genes in the future.
\end{abstract}

Keywords: Diversity Array Technology (DArT) markers; Hordeum vulgare L. ssp. vulgare; drought stress; quantitative trait loci (QTL) mapping; genome-wide association (GWA)

\section{Introduction}

Drought is one of the major environmental stresses restricting crop productivity and occurs largely due to the effects of global climate change, the depletion of the underground water table, and erratic rainfall patterns $[1,2]$. The tolerance of crops to drought stress is a complex quantitative trait that involves a number of physiobiochemical processes at the cellular and organism levels during plant development [3]. Plants adapt to drought stress by developing a thicker cuticle and wax [4] and closing stomata to reduce water loss [5], promoting deeper root systems to increase water uptake [6], 
reducing high levels of reactive oxygen species (ROS) [7], and accumulating osmolytes to regulate cellular osmolality [8].

Barley (Hordeum vulgare L. ssp. vulgare) is one of the most widely cultivated cereal crops in the world and a suitable model crop for research into drought tolerance [9]. Tibetan annual wild barley (Hordeum vulgare L. ssp. Spontaneum) is considered a progenitor of cultivated barley, and its growth in the harsh environment of the Qinghai-Tibet Plateau has resulted in substantially greater genetic variation and stress tolerance than cultivated barley $[10,11]$. In a previous study, we evaluated the genetic diversity of cultivated and Tibetan wild barley using 20 genomic simple sequence repeat (SSR) and 49 expressed sequence tag SSR (EST-SSR) markers and identified 213 alleles [12]. The polymorphism information content (PIC), a value often used as an informative measure of a genetic marker in linkage studies, was 0.44 and 0.37 for the wild and cultivated barley, respectively. Thus, the Tibetan wild barley is likely to provide germplasm containing genes confer drought tolerance that can be introduced into cultivated barley to produce high-yielding cultivars with increasing yield stability under drought stress.

Genome-wide association (GWA) mapping, also known as linkage disequilibrium mapping, is an excellent molecular genetic analysis tool to detect marker-trait associations. Compared with the biparental mapping of quantitative trait loci (QTL), GWA has a higher mapping resolution and it is not limited to alleles segregating among the biparental populations [13]. GWA mapping has been conducted to successfully link molecular markers to important traits in rice [14], maize [15], wheat [16] and barley [17] and is being extended to other crops along with the development of high-throughput marker-genotyping and sequencing technologies [18]. Most of the reported QTLs for drought tolerance in barley are for yield and yield components under water-limited conditions [19,20]. Hu et al. [21] identified 913 quantitative trait nucleotides associated with 14 agronomic traits related to yield of barley using doubled haploid lines. Jabbari et al. [22] identified 167 marker trait associations for 11 yield components of modern European spring barley cultivars under drought stress. However, little information is available for QTLs associated with the morphological and physiological traits for Tibetan wild barley under drought stress.

A hydroponic experiment and a pot trial were undertaken to identify marker-trait associations for agronomic and physiological traits of Tibetan wild barley under drought stress. We evaluated the population structure, linkage disequilibrium (LD) decay, and phenotypic variation of Tibetan wild barley accessions to determine the associations between diversity array technology (DArT) markers and phenotypes relevant to drought tolerance. Moreover, we identified the major alleles and candidate genes for drought tolerance in Tibetan wild barley.

\section{Results}

\subsection{Phenotypic Variation of Morphological Traits in Wild Barley}

The frequency distributions of the morphological parameters in the hydroponic experiment are shown in Figure 1. Large differences were found for relative shoot dry weight (RSDW) and relative root dry weight (RRDW) among the accessions, with values ranging from 0.42 to 0.98 and 0.42 to 1.48, respectively (Figure 1a,b). The root-to-shoot dry weight ratio (R: S) was also evaluated, with the relative values ranging from 0.63 to 2.12 . Relative shoot height (RSH) and relative root length (RRL) ranged from 0.57 to 0.84 and 0.26 to 0.79 , respectively (Figure 1c-f; Table 1 ). The results of correlation analysis showed that there were significant positive correlations between RSFW, RRFW, RSDW and RRDW $(p<0.01)$ (Table 2). RSH showed strong positive correlations with RSFW, RRFW, RSDW and RRDW, but RRL only significantly positively correlated with RSDW $(p<0.01)$. In the pot experiment, RSDW varied from 0.20 to 1.14 with an average of 0.66 , which is consistent with that in the hydroponic experiment (Figure 2a). The relative values of awn length (RAL) and grain weight per spike (RGW) ranged from 0.78 to 1.20 and 0.10 to 1.77 , respectively. There were significant 
positive correlations among RAL, RGW, relative ear length (REL), and relative internode length (RINL) $(p<0.01)$ (Figure 2f-h,j; Tables 1 and 3).

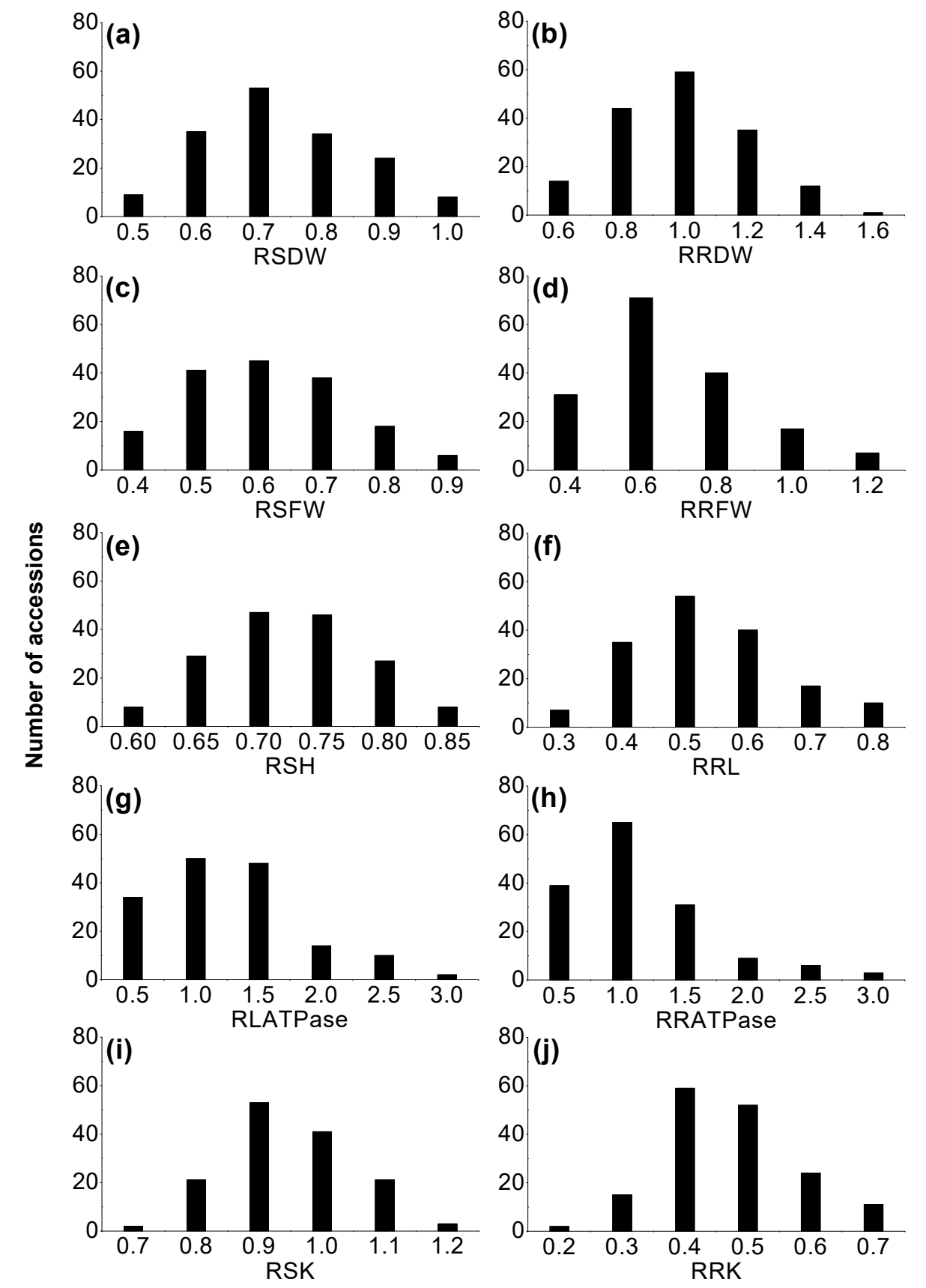

Figure 1. Frequency distribution of the relative value of different growth and physiological parameters of Tibetan wild barley plants under drought treatment in hydroponic experiment. Relative value of a given parameter was calculated as parameters under drought stress relative to control conditions (i.e., relative value $=($ parameter under drought stress $) /($ parameter under control)). (a) RSDW, relative shoot dry weight; (b) RRDW, relative root dry weight; (c) RSFW, relative shoot fresh weight; (d) RRFW, relative root fresh weight; (e) RSH, relative shoot height; (f) RRL, relative root length; (g) RLATPase, relative activity of leaf ATPase; (h) RRATPase, relative activity of root ATPase; (i) RSK, relative K concentration in shoots; $(\mathrm{j}) \mathrm{RRK}$, relative $\mathrm{K}$ concentration in roots. 
Table 1. The relative values of growth and physiological parameters of 166 Tibetan wild barley genotypes in hydroponic and pot experiments, expressed as drought stress relative to control.

\begin{tabular}{|c|c|c|c|c|c|c|}
\hline Experiments & Traits & Minimum & Maximum & Average & CV (\%) & Between Genotypes \\
\hline \multirow{10}{*}{ Hydroponic } & RSDW & 0.42 & 0.98 & 0.69 & 18.0 & $* *$ \\
\hline & RRDW & 0.42 & 1.48 & 0.90 & 23.6 & $* *$ \\
\hline & RSFW & 0.26 & 0.96 & 0.57 & 23.3 & $* *$ \\
\hline & RRFW & 0.27 & 1.16 & 0.57 & 34.2 & $* *$ \\
\hline & RSH & 0.57 & 0.84 & 0.71 & 8.4 & $* *$ \\
\hline & RRL & 0.26 & 0.79 & 0.49 & 24.7 & $* *$ \\
\hline & RLATPase & 0.16 & 3.36 & 1.06 & 61.8 & $* *$ \\
\hline & RRATPase & 0.07 & 3.56 & 0.86 & 75.9 & $* *$ \\
\hline & RSK & 0.69 & 1.14 & 0.91 & 10.7 & $* *$ \\
\hline & RRK & 0.21 & 0.68 & 0.43 & 23.8 & $* *$ \\
\hline \multirow{10}{*}{ Pot } & RSDW & 0.20 & 1.14 & 0.66 & 29.9 & $* *$ \\
\hline & RPOD & 0.30 & 4.46 & 2.18 & 36.6 & $* *$ \\
\hline & RCAT & 0.34 & 6.99 & 2.02 & 74.7 & $* *$ \\
\hline & RMDA & 0.20 & 4.51 & 1.48 & 71.6 & $* *$ \\
\hline & RPro & 0.71 & 6.37 & 2.28 & 60.7 & $* *$ \\
\hline & REL & 0.52 & 1.38 & 0.93 & 17.1 & $* *$ \\
\hline & RAL & 0.78 & 1.20 & 1.01 & 8.4 & $* *$ \\
\hline & RINL & 0.29 & 1.33 & 0.65 & 30.8 & $* *$ \\
\hline & RSK & 0.37 & 1.13 & 0.80 & 18.6 & $* *$ \\
\hline & RGW & 0.10 & 1.77 & 0.71 & 37.4 & $* *$ \\
\hline
\end{tabular}

Note: CV: Coefficient of variation. ${ }^{* *}$, Significant at the 0.01 probability levels between genotypes. Traits of Hydroponic Experiment: RSDW, relative shoot dry weight; RRDW, relative root dry weight; RSFW, relative shoot fresh weight; RRFW, relative root fresh weight; RSH, relative shoot height; RRL, relative root length; RLATPase, relative activity of leaf ATPase; RRATPase, relative activity of root ATPase; RSK, relative K concentration in shoots; RRK, relative K concentration in roots. Traits of Pot Experiment: RSDW, relative shoot dry weight; RPOD, relative peroxidase (POD) activity in leaf; RCAT: relative catalase (CAT) activity in leaf; RMDA: relative malondialdehyde (MDA) content in leaf; RPro, relative soluble protein content in leaf; REL: relative ear length; RAL: relative awn length; RINL: relative internode length below spike; RGW: relative grain weight per spike.

Table 2. The correlation coefficient among the parameters of growth and physiological traits of 166 Tibetan wild barley genotypes in the hydroponic experiment.

\begin{tabular}{|c|c|c|c|c|c|c|c|c|c|c|}
\hline & RSDW & RRDW & RSFW & RRFW & RLATPase & RRATPase & RSH & RRL & RSK & RRK \\
\hline RSDW & 1.000 & & & & & & & & & \\
\hline RRDW & $0.479 * *$ & 1.000 & & & & & & & & \\
\hline RSFW & 0.896 ** & $0.375^{* *}$ & 1.000 & & & & & & & \\
\hline RRFW & $0.400 * *$ & $0.730^{* *}$ & $0.362 * *$ & 1.000 & & & & & & \\
\hline RLATPase & 0.110 & 0.168 * & -0.033 & 0.142 & 1.000 & & & & & \\
\hline RRATPase & 0.067 & 0.090 & 0.031 & -0.023 & $0.554 * *$ & 1.000 & & & & \\
\hline RSH & $0.440 * *$ & $0.189 *$ & $0.548 * *$ & $0.303^{* *}$ & -0.034 & 0.058 & 1.000 & & & \\
\hline RRL & 0.155 * & -0.059 & -0.095 & -0.200 & $-0.280 * *$ & 0.019 & 0.006 & 1.000 & & \\
\hline RSK & $-0.409^{* *}$ & 0.029 & -0.078 & 0.072 & -0.117 & -0.077 & -0.093 & 0.085 & 1.000 & \\
\hline RRK & 0.067 & 0.171 * & 0.185 * & $0.303^{* *}$ & 0.066 & 0.024 & 0.170 * & -0.007 & -0.010 & 1.000 \\
\hline
\end{tabular}

Note: ${ }^{*}$ and ${ }^{* *}$, Significant at the 0.05 and 0.01 probability levels between genotypes, respectively.

Table 3. The correlation coefficient among the parameters of growth and physiological traits of 166 Tibetan wild barley genotypes in the pot experiment.

\begin{tabular}{|c|c|c|c|c|c|c|c|c|c|c|}
\hline & RSDW & RSK & RPOD & RCAT & RMDA & RPro & RAL & RINL & REL & RGW \\
\hline RSDW & 1.000 & & & & & & & & & \\
\hline RSK & -0.112 & 1.000 & & & & & & & & \\
\hline RPOD & -0.012 & $0.210^{* *}$ & 1.000 & & & & & & & \\
\hline RCAT & 0.067 & 0.051 & -0.066 & 1.000 & & & & & & \\
\hline RMDA & -0.073 & $0.259^{* *}$ & -0.075 & -0.032 & 1.000 & & & & & \\
\hline RPro & 0.163 * & 0.126 & -0.133 & $0.410^{* *}$ & $0.384^{* *}$ & 1.000 & & & & \\
\hline RAL & 0.122 & -0.050 & -0.135 & -0.036 & 0.039 & 0.012 & 1.000 & & & \\
\hline RINL & 0.081 & -0.056 & $-0.187^{*}$ & 0.005 & $0.157^{*}$ & $0.223^{* *}$ & $0.329 * *$ & 1.000 & & \\
\hline REL & 0.118 & -0.058 & $-0.255^{* *}$ & 0.027 & 0.129 & 0.153 & $0.515^{* *}$ & $0.551 * *$ & 1.000 & \\
\hline RGW & 0.202 ** & -0.138 & $-0.224^{* *}$ & -0.059 & 0.126 & 0.172 * & 0.396 ** & $0.289 * *$ & $0.554^{* *}$ & 1.000 \\
\hline
\end{tabular}

Note: * and ${ }^{* *}$, Significant at the 0.05 and 0.01 probability levels between genotypes, respectively. 

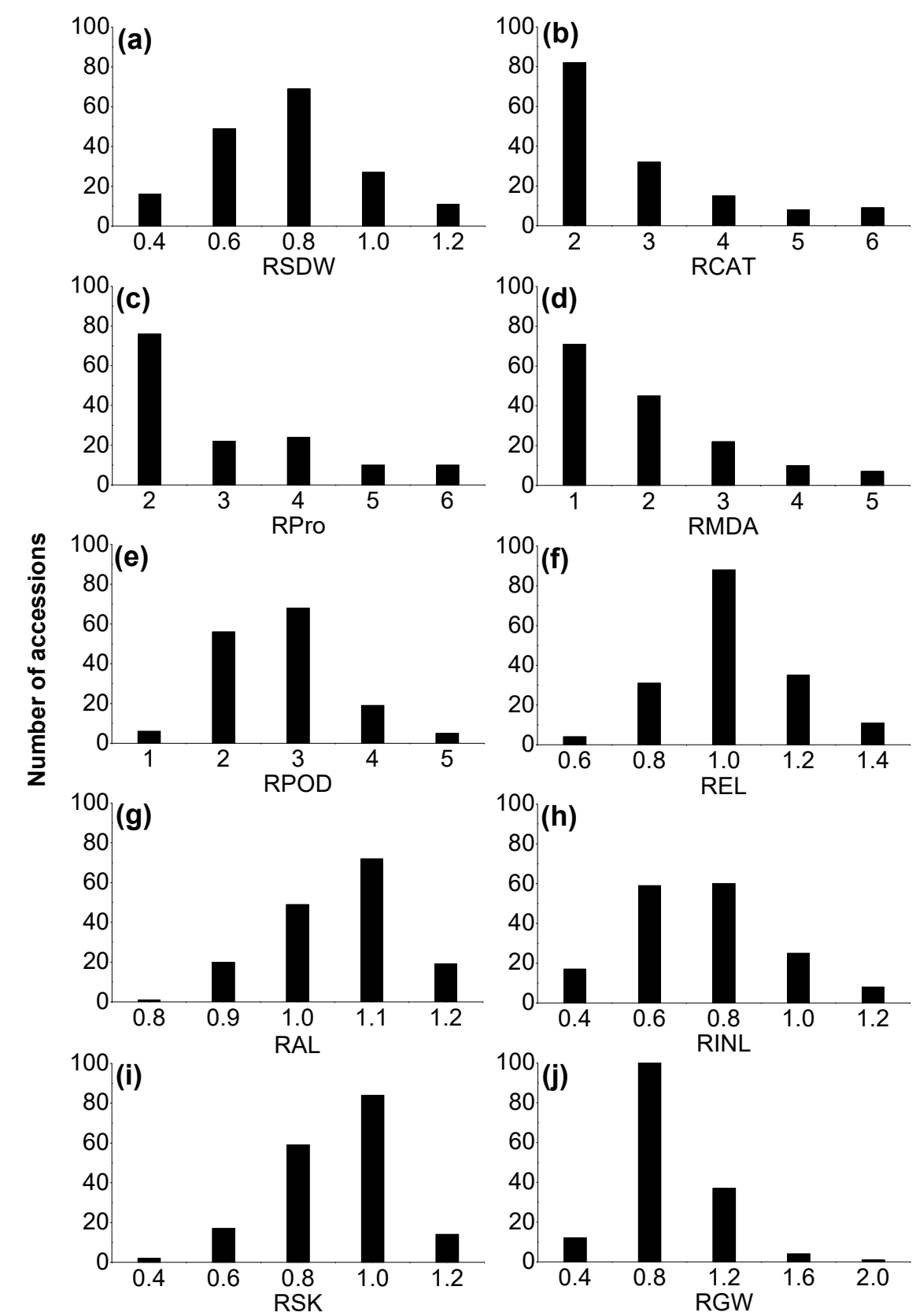

Figure 2. Frequency distribution of the relative value of different traits of Tibetan wild barley plants under drought treatment in pot experiment. Relative value of a given parameter was calculated as parameters under drought stress relative to control conditions (i.e., relative value $=$ (parameter under drought stress)/(parameter under control)). (a) RSDW, relative shoot dry weight; (b) RCAT, relative catalase (CAT) activity in leaf; (c) RPro, relative soluble protein content in leaf; (d) RMDA: relative malondialdehyde (MDA) content in leaf; (e) RPOD, relative peroxidase (POD) activity in leaf; (f) REL: relative ear length; (g) RAL: relative awn length; (h) RINL: relative internode length below spike; (i) RSK, relative K concentration in shoots;(j) RGW: relative grain weight per spike.

2.2. Variation in $H^{+} K^{+}$-ATPase and Antioxidant Enzyme Activities, Malondialdehyde (MDA) and Soluble Protein Contents

In the hydroponic experiment, the relative values of $\mathrm{H}^{+} \mathrm{K}^{+}$-ATPase activity of leaves (RLATPase) and roots (RRATPase) ranged from 0.16 to 3.36 and 0.07 to 3.56, respectively (Figure 1g,h), which were significantly and positively correlated $(p<0.01)$. Furthermore, it is worth noting that RLATPase was significantly and positively correlated with RRDW $(p<0.05)$ (Table 2$)$. 
In the pot experiment, the relative values of catalase (RCAT) and peroxidase (RPOD) activities, varied from 0.34 to 6.99 and 0.30 to 4.46, respectively (Figure 2b,e; Table 1). Large differences were also found in the relative values of soluble protein (RPro) and MDA contents (RMDA) among the accessions, ranging from 0.71 to 6.37 and 0.20 to 4.51, respectively (Figure 2c,d; Table 1). RPro also showed significant and positive causal links with RCAT, RMDA, and RSDW (Table 3).

\subsection{Phenotypic Variation in $\mathrm{K}^{+}$Concentration in Wild Barley}

In the hydroponic trial, 7 days of drought stress caused substantial variation in the relative values of the $\mathrm{K}^{+}$concentration in shoots (RSK) and roots (RRK) among the accessions, ranging from 0.69 to 1.14 and from 0.21 to 0.68 , averaged at 0.91 and 0.43 , respectively (Figure 1i,j; Table 1). RRK correlated significantly and positively with RRFW and RRDW; in contrast, RSK had significantly negative correlation with RSDW $(p<0.01)$ (Table 2).

In the pot experiment, there was also a large variation in RSK, ranging from 0.37 to 1.13 with a mean at 0.80 (Figure 2i) after 30 days of drought stress. RSK was also negatively correlated with RSDW (Table 3). RSK was also highly positively correlated with RPOD and RMDA $(p<0.01)$.

\subsection{Population Structure and Linkage Disequilibrium Decay}

The population structure of the 166 barley accessions was analyzed using STRUCTURE and the 777 DArT markers. The most suitable number of subpopulations for association analysis was determined based on the highest $\Delta \mathrm{k}$ value $=3$ (Figure 3a). The three subpopulations consisted of 69, 73 and 24 accessions (Figure 3b; Table S1).

(a)

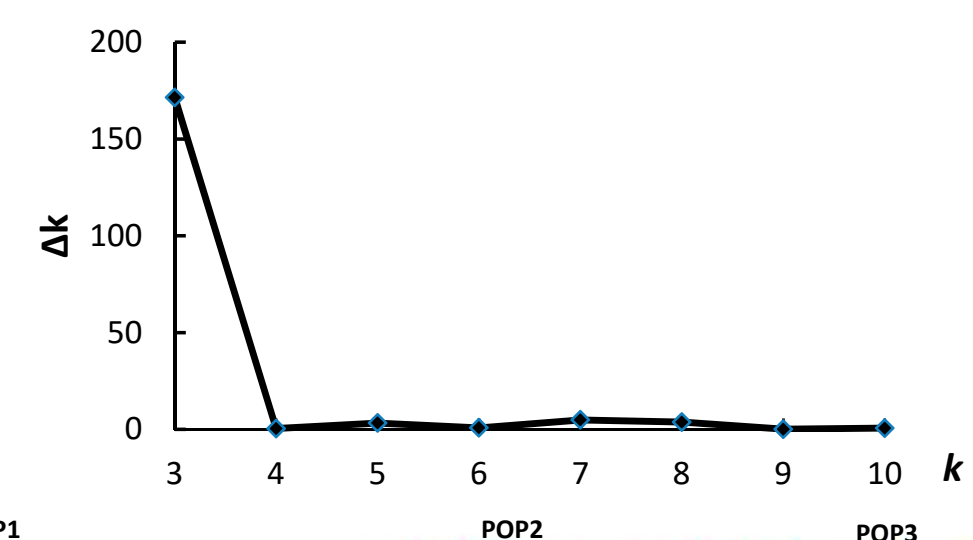

(b)

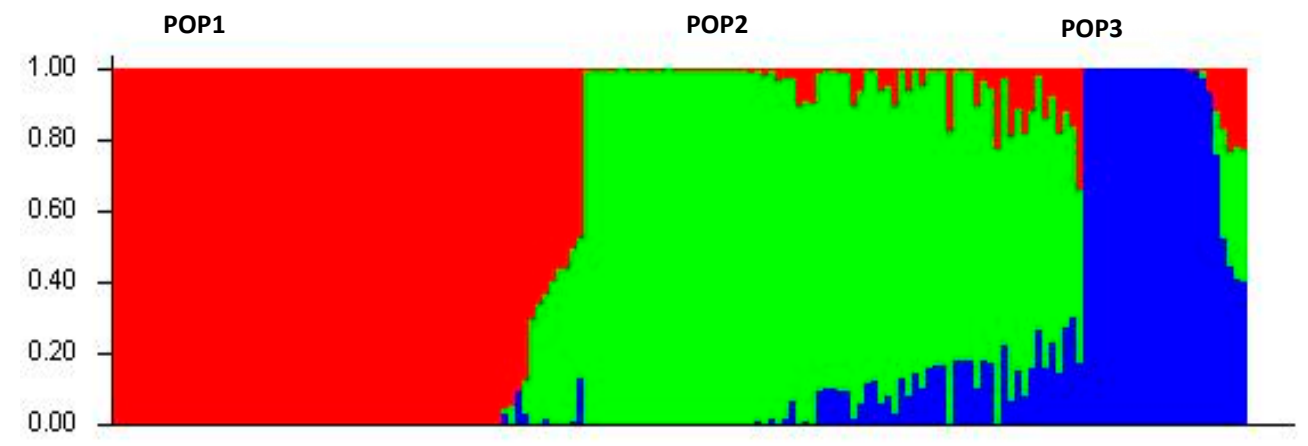

Figure 3. (a) The distribution of $\Delta \mathrm{k}$, indicating the most appropriate cluster number $(k)$ is three; (b) Population structure of 166 Tibetan wild barley genotypes at $k=3$ based on genetic diversity detected by 777 DArT markers.

Linkage disequilibrium (LD) decay in the seven chromosomes of the wild barley accessions was deemed to have occurred when $r^{2} \leq 0.1$. The results showed that the minimum LD decay distance is $0.03 \mathrm{cM}$ on chromosome $6 \mathrm{H}$ and the maximum LD decay distance was $23.48 \mathrm{cM}$ on chromosome $4 \mathrm{H}$, with an average distance of $5.16 \mathrm{cM}$ (Figure S1). 


\subsection{Identification of Loci Associated with Morphological Traits}

In order to detect candidate loci for drought tolerance, a genome wide association analysis was performed using the 777 DArT markers and the traits determined under drought stress in both experiments. Based on a statistical significance level of $p \leq 0.001$, a total of 91 marker-trait associations were detected in this study (Tables 4 and 5), among which 33 markers were associated with morphological traits (Table 4). For RRDW, 11 associations were detected on chromosomes $1 \mathrm{H}$, $2 \mathrm{H}, 3 \mathrm{H}, 4 \mathrm{H}$ and $7 \mathrm{H}$ and, these markers represented $9.8-15.6 \%$ of the phenotypic variation. The data from the pot experiment identified one marker (bpb-3653) on $2 \mathrm{H}$ associated with RSDW, explaining $9.4 \%$ of the phenotypic variation. In the hydroponic experiment, there were four and two associations with RSH and RRL, and these loci explained $9.1-10.5 \%$ and $8.9-12.3 \%$ of the phenotypic variation, respectively. Furthermore, 14 markers were associated with awn length (AL), and a major locus (bpb-0068) located at $66.50 \mathrm{cM}$ on chromosome $3 \mathrm{H}$ contributed to $19.8 \%$ of the phenotypic variation. In addition, marker bpb-4184 on $2 \mathrm{H}$ was associated with both AL and internode length (INL) and explained $12.4 \%$ and $9.7 \%$ of the phenotypic variation, respectively.

Table 4. List of DArT markers with significant marker-trait association of morphological traits.

\begin{tabular}{|c|c|c|c|c|c|}
\hline Traits & Marker & Chromosome & Distance (cM) & $-\log _{10}(p)$ & $r^{2}(\%)$ \\
\hline \multirow{11}{*}{ RRDW } & bPb-9005 & $1 \mathrm{H}$ & 67.88 & 4.72 & 13.0 \\
\hline & $\mathrm{bPb}-4481$ & $2 \mathrm{H}$ & 18.81 & 4.37 & 13.1 \\
\hline & $\mathrm{bPb}-0827$ & $2 \mathrm{H}$ & 86.41 & 4.34 & 14.2 \\
\hline & bPb-0775 & $2 \mathrm{H}$ & 140.87 & 4.34 & 13.0 \\
\hline & $\mathrm{bPb}-2203$ & $3 \mathrm{H}$ & 35.93 & 5.16 & 15.6 \\
\hline & $\mathrm{bPb}-8013$ & $4 \mathrm{H}$ & 86.69 & 3.37 & 13.3 \\
\hline & bPb-6096 & $4 \mathrm{H}$ & 96.78 & 3.33 & 9.8 \\
\hline & bPb-3491 & $7 \mathrm{H}$ & 100.50 & 4.44 & 9.9 \\
\hline & bPb-6384 & $7 \mathrm{H}$ & 100.50 & 4.53 & 13.6 \\
\hline & $\mathrm{bPb}-3506$ & $7 \mathrm{H}$ & 101.20 & 4.53 & 13.6 \\
\hline & bPb-8037 & $7 \mathrm{H}$ & 160.68 & 4.40 & 13.2 \\
\hline \multirow{4}{*}{$\mathrm{RSH}$} & $\mathrm{bPb}-1127$ & $1 \mathrm{H}$ & 57.23 & 3.35 & 9.9 \\
\hline & bPb-9336 & $3 \mathrm{H}$ & 100.76 & 3.48 & 10.3 \\
\hline & bPb-8419 & $3 \mathrm{H}$ & 153.55 & 3.11 & 9.1 \\
\hline & $\mathrm{bPb}-3375$ & $6 \mathrm{H}$ & 122.08 & 3.57 & 10.5 \\
\hline RL & bPb-8935 & $1 \mathrm{H}$ & 118.95 & 4.14 & 12.3 \\
\hline RRL & bPb-9908 & $7 \mathrm{H}$ & 111.69 & 3.77 & 8.9 \\
\hline RSDW & $\mathrm{bPb}-3653$ & $2 \mathrm{H}$ & 108.05 & 3.05 & 9.4 \\
\hline \multirow{14}{*}{$\mathrm{AL}$} & bPb-2976 & $1 \mathrm{H}$ & 54.01 & 4.11 & 12.9 \\
\hline & $\mathrm{bPb}-5334$ & $1 \mathrm{H}$ & 67.88 & 4.25 & 13.4 \\
\hline & bPb-5444 & $2 \mathrm{H}$ & 26.24 & 3.38 & 10.5 \\
\hline & bPb-4184 & $2 \mathrm{H}$ & 119.90 & 3.95 & 12.4 \\
\hline & bPb-1264 & $3 \mathrm{H}$ & 5.97 & 3.80 & 9.6 \\
\hline & $\mathrm{bPb}-0068$ & $3 \mathrm{H}$ & 66.50 & 6.09 & 19.8 \\
\hline & bPb-6611 & $4 \mathrm{H}$ & 60.55 & 4.27 & 13.5 \\
\hline & bPb-9820 & $4 \mathrm{H}$ & 142.09 & 4.16 & 13.1 \\
\hline & bPb-1485 & $5 \mathrm{H}$ & 81.35 & 4.07 & 12.8 \\
\hline & $\mathrm{bPb}-2835$ & $5 \mathrm{H}$ & 81.35 & 3.56 & 11.1 \\
\hline & $\mathrm{bPb}-8022$ & $5 \mathrm{H}$ & 101.34 & 3.33 & 10.4 \\
\hline & $\mathrm{bPb}-8553$ & $5 \mathrm{H}$ & 120.44 & 4.09 & 12.9 \\
\hline & $\mathrm{bPb}-4457$ & $7 \mathrm{H}$ & 3.02 & 4.41 & 13.9 \\
\hline & bPb-8051 & $7 \mathrm{H}$ & 78.22 & 3.25 & 10.1 \\
\hline INL & $\mathrm{bPb}-4184$ & $2 \mathrm{H}$ & 119.90 & 3.15 & 9.7 \\
\hline
\end{tabular}


Table 5. List of DArT markers with significant marker-trait association of physiological traits.

\begin{tabular}{|c|c|c|c|c|c|}
\hline Traits & Marker & Chromosome & Distance (cM) & $-\log _{10}(p)$ & $r^{2}(\%)$ \\
\hline \multirow{16}{*}{ RRATPase } & $\mathrm{bPb}-3217$ & $1 \mathrm{H}$ & 40.53 & 3.34 & 12.4 \\
\hline & bPb-6911 & $1 \mathrm{H}$ & 94.90 & 4.07 & 15.3 \\
\hline & bPb-9121 & $1 \mathrm{H}$ & 94.90 & 4.08 & 15.3 \\
\hline & bPb-4144 & $1 \mathrm{H}$ & 94.90 & 3.06 & 11.3 \\
\hline & bPb-4877 & $2 \mathrm{H}$ & 47.38 & 3.03 & 11.2 \\
\hline & bPb-8779 & $2 \mathrm{H}$ & 77.41 & 3.03 & 11.2 \\
\hline & bPb-1593 & $2 \mathrm{H}$ & 149.44 & 3.11 & 11.5 \\
\hline & bPb-8255 & $2 \mathrm{H}$ & 149.44 & 3.85 & 14.4 \\
\hline & bPb-6884 & $3 \mathrm{H}$ & 0.98 & 4.09 & 15.3 \\
\hline & $\mathrm{bPb}-3025$ & $3 \mathrm{H}$ & 9.88 & 3.05 & 11.3 \\
\hline & bPb-1137 & $3 \mathrm{H}$ & 10.20 & 6.00 & 23.2 \\
\hline & bPb-2548 & $3 \mathrm{H}$ & 48.32 & 4.68 & 17.7 \\
\hline & bPb-9299 & $6 \mathrm{H}$ & 14.35 & 5.44 & 20.8 \\
\hline & bPb-3921 & $6 \mathrm{H}$ & 38.16 & 4.35 & 16.4 \\
\hline & bPb-3722 & $6 \mathrm{H}$ & 68.53 & 5.83 & 22.5 \\
\hline & bPb-7399 & $7 \mathrm{H}$ & 94.41 & 3.13 & 11.6 \\
\hline \multirow{3}{*}{ RLATPase } & bPb-9957 & $1 \mathrm{H}$ & 63.32 & 3.37 & 8.1 \\
\hline & bPb-3921 & $6 \mathrm{H}$ & 38.16 & 3.37 & 10.1 \\
\hline & $\mathrm{bPb}-4369$ & $6 \mathrm{H}$ & 74.34 & 3.11 & 9.4 \\
\hline \multirow{6}{*}{ RATPase } & bPb-8081 & $1 \mathrm{H}$ & 116.46 & 3.01 & 12.7 \\
\hline & bPb-6884 & $3 \mathrm{H}$ & 0.98 & 4.09 & 17.5 \\
\hline & bPb-1137 & $3 \mathrm{H}$ & 10.20 & 4.46 & 19.2 \\
\hline & bPb-9299 & $6 \mathrm{H}$ & 14.35 & 3.17 & 13.4 \\
\hline & bPb-3722 & $6 \mathrm{H}$ & 68.53 & 4.35 & 18.7 \\
\hline & bPb-6607 & $6 \mathrm{H}$ & 84.64 & 3.48 & 14.8 \\
\hline LATPase & bPb-8779 & $2 \mathrm{H}$ & 77.41 & 3.06 & 9.2 \\
\hline \multirow{4}{*}{ RSK } & bPb-3382 & $1 \mathrm{H}$ & 66.24 & 4.73 & 14.4 \\
\hline & bPb-0689 & $2 \mathrm{H}$ & 157.09 & 4.72 & 14.4 \\
\hline & bPb-3045 & $4 \mathrm{H}$ & 65.34 & 4.42 & 13.4 \\
\hline & bPb-9908 & $7 \mathrm{H}$ & 111.69 & 4.72 & 14.4 \\
\hline \multirow{2}{*}{ RRK } & bPb-0910 & $1 \mathrm{H}$ & 59.42 & 3.10 & 9.1 \\
\hline & bPb-9957 & $1 \mathrm{H}$ & 63.32 & 3.25 & 7.6 \\
\hline \multirow{4}{*}{ SK } & bPb-3382 & $1 \mathrm{H}$ & 66.24 & 3.22 & 9.6 \\
\hline & bPb-0689 & $2 \mathrm{H}$ & 157.09 & 3.25 & 9.7 \\
\hline & bPb-3045 & $4 \mathrm{H}$ & 65.34 & 3.49 & 10.5 \\
\hline & bPb-9908 & $7 \mathrm{H}$ & 111.69 & 3.29 & 9.8 \\
\hline MDA & $\mathrm{bPb}-7723$ & $2 \mathrm{H}$ & 163.34 & 4.00 & 12.8 \\
\hline POD & bPb-8737 & $2 \mathrm{H}$ & 108.72 & 3.07 & 9.5 \\
\hline RPOD & bPb-5755 & $2 \mathrm{H}$ & 133.29 & 3.35 & 10.6 \\
\hline \multirow{3}{*}{ RPro } & bPb-9957 & $1 \mathrm{H}$ & 63.32 & 6.72 & 20.2 \\
\hline & bPb-5403 & $7 \mathrm{H}$ & 159.05 & 3.06 & 7.8 \\
\hline & bPb-6701 & $7 \mathrm{H}$ & 159.19 & 3.06 & 7.8 \\
\hline \multirow{2}{*}{ SK (soil) } & bPb-1447 & $7 \mathrm{H}$ & 78.22 & 3.21 & 9.4 \\
\hline & bPb-8112 & $1 \mathrm{H}$ & 140.85 & 3.14 & 9.2 \\
\hline \multirow{14}{*}{ RCAT } & bPb-0994 & $2 \mathrm{H}$ & 113.25 & 3.43 & 9.3 \\
\hline & bPb-4601 & $2 \mathrm{H}$ & 157.00 & 5.69 & 16.1 \\
\hline & bPb-1857 & $3 \mathrm{H}$ & 0.98 & 3.43 & 9.4 \\
\hline & bPb-9599 & $3 \mathrm{H}$ & 149.85 & 3.40 & 9.3 \\
\hline & bPb-0347 & $3 \mathrm{H}$ & 175.25 & 4.89 & 13.6 \\
\hline & bPb-7069 & $3 \mathrm{H}$ & 178.60 & 8.66 & 25.7 \\
\hline & $\mathrm{bPb}-7063$ & $3 \mathrm{H}$ & 178.60 & 8.66 & 25.7 \\
\hline & bPb-8580 & $5 \mathrm{H}$ & 8.49 & 4.98 & 13.9 \\
\hline & bPb-3792 & $5 \mathrm{H}$ & 45.58 & 5.07 & 14.2 \\
\hline & bPb-5584 & $5 \mathrm{H}$ & 54.10 & 5.28 & 14.8 \\
\hline & bPb-2304 & $6 \mathrm{H}$ & 136.06 & 8.89 & 26.4 \\
\hline & bPb-7146 & $6 \mathrm{H}$ & 137.76 & 4.40 & 12.2 \\
\hline & bPb-1621 & $6 \mathrm{H}$ & 137.76 & 5.17 & 14.5 \\
\hline & bPb-0783 & $7 \mathrm{H}$ & 160.68 & 4.71 & 13.1 \\
\hline
\end{tabular}


2.6. Identification of Loci Associated with $\mathrm{H}^{+} \mathrm{K}^{+}$-ATPase and the Antioxidant Enzyme Activities, Malondialdehyde and Soluble Protein Contents

As shown in Table 5, there were 26 loci associated with leaf and root $\mathrm{H}^{+} \mathrm{K}^{+}$-ATPase activity under drought stress. Twenty-two associations with $\mathrm{H}^{+} \mathrm{K}^{+}$-ATPase were detected in root explaining between $11.2-23.2 \%$ of the phenotypic variation. Especially, markers bpb-1137 on $3 \mathrm{H}$ and bpb-3722 and bpb-9299 on $6 \mathrm{H}$ explained $23.2 \%, 22.5 \%$ and $20.8 \%$ of phenotypic variation for RRATPase, respectively (Table 5). It was noticeable that these three major loci and bpb-6884 on $3 \mathrm{H}$ were also associated with root $\mathrm{H}^{+} \mathrm{K}^{+}$-ATPase (RATPase) activity. Markers, bpb-3921 and bpb-8779, associated with RLATPase and leaf $\mathrm{H}^{+} \mathrm{K}^{+}$-ATPase (LATPase), respectively, were also linked to RRATPase (Table 5).

With respect to the antioxidative system, 2 and 14 associations were detected for POD and CAT activity, respectively (Table 5). For CAT activity, the 14 loci explained from $9.3 \%$ to $26.4 \%$ of the phenotypic variation, among which three major loci, bpb-2304, bpb-7063 and bpb-7069 contributed to $26.4 \%, 25.7 \%$ and $25.7 \%$ of the phenotypic variation, respectively.

Among the three markers associated with soluble protein content, a major locus on $1 \mathrm{H}$ (bpb-9957) explained $20.2 \%$ of the phenotypic variation. It is worth noting that three phenotypic parameters-RLATPase, RPro and RRK - were all associated with bpb-9957, suggesting that this marker may be significantly correlated with drought tolerance. There was only one marker, bpb-7723, associated with MDA content, explaining $12.8 \%$ of the phenotypic variation.

\subsection{Identification of Loci Associated with $\mathrm{K}^{+}$Concentration}

For the shoot $\mathrm{K}^{+}$concentration, four markers, bpb-3382, bpb-0689, bpb-3045 and bpb-9908, were associated with both RSK and shoot $\mathrm{K}^{+}$concentration (SK), each contributing to $13.4-14.4 \%$ and 9.6-10.5\% of phenotypic variation, respectively (Table 5). There were two closely linked associations (bpb-0910 and bpb-9957) located at 59.42 and $63.32 \mathrm{cM}$ on $1 \mathrm{H}$ for root $\mathrm{K}^{+}$concentration, explaining $9.1 \%$ and $7.6 \%$ of the phenotypic variation, respectively. In the pot experiment, two associations (bpb- 8112 on $1 \mathrm{H}$ and bpb-1447 on $7 \mathrm{H}$ ) were detected, explaining $9.2 \%$ and $9.4 \%$ of the phenotypic variation, respectively (Table 5).

\section{Discussion}

The present study reemphasizes the genetic diversity of Tibetan annual wild barley from the Qinghai-Tibet Plateau with potential genes and traits for drought stress tolerance. There were large differences in morphological traits, enzyme activities and $\mathrm{K}^{+}$concentration, suggesting different mechanisms of drought tolerance among the accessions (Figures 1-3).

\subsection{Quantitative Trait Loci (QTL) Associated with Morphological Traits under Drought Stress}

Drought stress reduces shoot biomass of the barley accessions, but the mechanisms of drought response may be different in hydroponic and pot experiments. Similar reduction of RSDW in the hydroponic and pot experiments is in agreement with the findings of previous studies [3,23]. The results also showed that RRDW was higher than RSDW in the hydroponic experiment resulting in an increased root-to-shoot ratio under drought stress, indicating that a greater proportion of assimilated carbon was allocated to roots [24]. The significant positive correlation between RSDW and RRL (Table 2) suggests that deeper rooting mechanism may have resulted in greater shoot biomass and improved drought tolerance. A higher root-to-shoot ratio during drought was found to be combined with a relatively deeper distribution of roots [25]. A plant able to access water deep in soil at reduced metabolic cost will have superior productivity, because root construction and maintenance require metabolic investment [26].

The sequences of DArT markers associated with traits of barley under drought stress were aligned on Barleymap (http: / / floresta.eead.csic.es/barleymap /, accessed on 22th, April, 2017) to search the genes close to DArT markers, based on intervals of $5 \mathrm{cM}$ (Table 6). The markers associated with root 
dry weight, bpb-9005 and bpb-3491, were close to two genes, MLOC_59277 and MLOC_74469, both involved in lateral root primordium (LRP) protein. Sehgal et al. [27] indicated that the assimilate supply reduction under drought stress strongly influenced grain development, by decreasing assimilate production and mobilization to seeds in crops. In barley, $76 \%$ of the seed dry weight constitutes carbohydrates derived from the photosynthetic organs (lemma, palea and awn) of the spike [28] where awn is the major photosynthetic organ [29]. Previous studies revealed that the contribution of spike photosynthesis to grain-filling is greater during drought, as the flag leaves wilt under drought while the spike is more resilient and adapted to drought stress due to its better osmotic adjustment, high water use efficiency and delayed senescence [30-32]. The significant positive correlation (Table 3) between the awn length and grain weight per spike in this study further confirms that awn contributes to the photosynthesis and grain-filling of spikes during the reproductive stage of barley under drought stress [33].

Table 6. The function description of genes close to DArT markers by searching Barleymap.

\begin{tabular}{|c|c|c|c|c|c|c|}
\hline Trait & Marker & Chromosome & cM & Gene & cM & Description \\
\hline \multirow[t]{2}{*}{ RRDW } & bPb-9005 & $1 \mathrm{H}$ & 54.39 & MLOC_59277 & 52.51 & $\begin{array}{l}\text { Lateral root primordium (LRP) } \\
\text { protein-related }\end{array}$ \\
\hline & bPb-3491 & $7 \mathrm{H}$ & 89.14 & MLOC_74469 & 89.14 & $\begin{array}{l}\text { Lateral root primordium (LRP) } \\
\text { protein-related }\end{array}$ \\
\hline \multirow{11}{*}{ RRATPase } & bpb-4144 & $1 \mathrm{H}$ & 87.87 & MLOC_13794 & 90.3 & ATP-binding cassette transporter \\
\hline & & & & MLOC_58493 & 90.3 & ABC (ATP-binding) family transporter \\
\hline & bpb-3722 & $6 \mathrm{H}$ & 54.89 & MLOC_68594 & 52.83 & Potassium transporter \\
\hline & & & & MLOC_46910 & 53.6 & AAA-type ATPase family protein \\
\hline & & & & MLOC_57716 & 53.61 & ATPase 7B; Copper-transporting ATPase 2 \\
\hline & & & & MLOC_10111 & 53.9 & Potassium channel \\
\hline & & & & MLOC_72084 & 54.82 & ADP, ATP carrier protein 1 \\
\hline & & & & $M L O C \_34488$ & 54.89 & ABC transporter ATP-binding protein \\
\hline & & & & MLOC_5994 & 55.03 & ATP-binding cassette transporter \\
\hline & bpb-7399 & $7 \mathrm{H}$ & 84.56 & MLOC_52035 & 84.57 & ATP-binding cassette transporter \\
\hline & & & & MLOC_13204 & 89.14 & Potassium transporter \\
\hline \multirow{2}{*}{$\begin{array}{c}\text { RRK } \\
\text { RLATPase }\end{array}$} & bpb-9957 & $1 \mathrm{H}$ & 47.83 & MLOC_37216 & 46.6 & $\mathrm{ABC}$ transporter ATP-binding protein \\
\hline & & & & MLOC_18422 & 47.83 & Phospholipid-transporting ATPase 3 \\
\hline \multirow{2}{*}{ RRK } & bPb-0910 & $1 \mathrm{H}$ & 46.81 & AK366430 & 48.09 & K Homology type 1 \\
\hline & & & & MLOC_5191.1 & 52.48 & K Homology type 1 subgroup \\
\hline POD & bPb-8737 & $2 \mathrm{H}$ & 98.52 & MLOC_25978 & 98.52 & Peroxidase 60 , putative \\
\hline \multirow{2}{*}{ RPOD } & $\mathrm{bPb}-5755$ & $2 \mathrm{H}$ & 119.76 & MLOC_66485 & 119.33 & Peroxidase 16 \\
\hline & & & & MLOC_15491 & 124.77 & Peroxidase \\
\hline \multirow{3}{*}{ RCAT } & $\mathrm{bPb}-4601$ & $2 \mathrm{H}$ & 144.12 & MLOC_65477 & 146.53 & Peroxidase 10 \\
\hline & & & & MLOC_54893 & 146.92 & Peroxidase 12 \\
\hline & bPb-2304 & $6 \mathrm{H}$ & 117.55 & MLOC_55199 & 117.55 & Peroxidase superfamily protein \\
\hline RPro & bPb-5403 & $7 \mathrm{H}$ & 138.22 & MLOC_78556 & 140.86 & High mobility group protein \\
\hline
\end{tabular}

\subsection{QTL Associated with $\mathrm{H}^{+} \mathrm{K}^{+}$-ATPase under Drought Stress}

The plasma membrane $\mathrm{H}^{+}$-ATPase plays important roles in plant development including powering the absorption and transport nutrients across membranes [34]. The function of $\mathrm{H}^{+}$-ATPase is to transport intracellular $\mathrm{H}^{+}$and extracellular $\mathrm{K}^{+}$across membranes by hydrolyzing ATP [35]. Under drought stress, increased $\mathrm{H}^{+}$-ATPase activity is an adaptive response of plants to prevent the direct or indirect dehydration of cell organelles [36]. The $\mathrm{pH}$ in the apoplast increases with the elevated $\mathrm{H}^{+}$-ATPase activity, and then ion channels and co-transporters are driven to transport the osmoregulation substances (e.g., $\mathrm{K}^{+}, \mathrm{Cl}^{-}$, organic acids) [37] into cells to decrease the cellular water potential. Gong et al. [38] demonstrated that drought stress can stimulate the activity of $\mathrm{H}^{+}$-ATPase by increasing the catalytic activity of its phosphatase domain. Our previous study [39] indicated that the drought tolerant Tibetan wild barley accessions $\mathrm{XZ} 5$ showed higher $\mathrm{H}^{+}$-ATPase activity under drought, low $\mathrm{pH}$ and $\mathrm{Al}$ combined stress. In this study, higher $\mathrm{H}^{+}$-ATPase and antioxidant enzymes activities was also observed in XZ5 with high tolerant to drought among the population. In addition, three markers bpb-4144, bpb-3722 and bpb-7399, associated with root $\mathrm{H}^{+} \mathrm{K}^{+}$-ATPase activity, were located close to 2, 7 and 2 genes on Barleymap (Table 6), among which there were 5 genes encoding 
ATP-binding cassette (ABC) transporters, 2 encoding ATPases, 2 potassium transporters, 1 potassium channel, and 1 ADP / ATP carrier protein. The marker bpb-9957 associated with root potassium content and leaf $\mathrm{H}^{+} \mathrm{K}^{+}$-ATPase activity, was close to two genes, MLOC_37216 and MLOC_18422, involved in $\mathrm{ABC}$ transporter and phospholipid-transporting ATPase 3, respectively. However, further studies are required to analyze the function of these genes and their roles in drought tolerance of Tibetan wild barley.

\subsection{QTL Associated with $\mathrm{K}^{+}$Concentration under Drought Stress}

There are many $\mathrm{K}^{+}$-dependent processes in plants, such as photosynthesis, osmoregulation and nutrition absorption [40-42]. Potassium ions can also improve plant tolerance to various abiotic stresses such as drought [41,43], $\mathrm{NaCl}[44,45]$ and waterlogging [46,47]. In the present study, the $\mathrm{K}^{+}$concentration in most barley accessions decreased under drought stress, due to the impaired transpiration rate and the reduced membrane permeability [48]. Recent studies show that $\mathrm{K}^{+}$efflux is important for sensing of ROS, induction of programmed cell death (PCD), and inhibition of energy-consuming biosynthesis $[49,50]$. Therefore, this may be another mechanism of potassium-regulated drought tolerance of Tibetan wild barley. Furthermore, this study identified two genes encoding K homology type 1, AK366430 and MLOC_5191.1, which were located close to the marker associated with root potassium content, bpb-0910 (Table 6). Two potassium transporters and one potassium channel genes were identified to be associated with RRATPase.

\subsection{QTL Associated with Peroxidase (POD) and Catalase (CAT) Activity under Drought Stress}

There was considerable variation among barley accessions for activities of antioxidant enzymes (e.g., POD and CAT), the contents of MDA and soluble protein (Figure 2). The increased MDA content indicated serious membrane lipid peroxidation, which is consistent with the increased antioxidant enzyme activities needed to scavenge the high levels of ROS [7,41,51]. Under drought stress, the increase of soluble protein may result from the synthesis of highly hydrophilic protein for resistance of dehydration [2,52]. By searching the Barleymap using DArT marker sequence, six genes encoding peroxidase were identified close to the markers associated with POD and CAT activity. Besides, the gene $M L O C_{-} 78556$ encoding high mobility group protein was close to the marker bpb-5403, associated soluble protein content (Table 6).

\subsection{The Effect of Population Structure and Linkage Disequilibrium (LD) on the Association Analysis}

Population structure analysis showed that three subpopulations are present in 166 Tibetan wild barley accessions. The grouping of the accessions into these subpopulations was in agreement with our previous study [12] using different markers, indicating the consistency in allocating the subpopulations. The presence of population stratification and an unequal distribution of alleles could result in non-functional and spurious associations [53]. Thus, the population structure was taken into account in this study. The average LD decay distance of $5.16 \mathrm{cM}$ and the randomly distributed 777 DArT markers over the barley genome ensured that these markers cover the whole genome and are sufficient for genome wide association analysis. LD decayed more rapidly on chromosome $6 \mathrm{H}$ $(0.03 \mathrm{cM})$ than $4 \mathrm{H}(23.48 \mathrm{cM})$, indicating that the results of GWA on $6 \mathrm{H}$ may provide higher resolution of fine mapping and gene discovery than those on $4 \mathrm{H}$.

\subsection{Comparison of Genome-Wide Association (GWA) Results with Reported Meta-QTL and Exploration of Candidate Genes}

The previous meta-analysis of QTL associated with tolerance to abiotic stresses in barley identified 26 metaQTL (MQTL) and 29 candidate genes for traits associated with drought tolerance [19]. The consensus map based on the MQTL was selected as the reference map in this study. Twelve DArT markers identified in the present study located at similar positions to 10 MQTLs on the reference 
map (Table S2). Zhang et al. [54] also projected four MQTL for drought tolerance to the physical map of barley through meta-analysis.

The marker bpb-9957 localized at $63.32 \mathrm{cM}$ on $1 \mathrm{H}$ was co-located to the MQTL D15 $(61.60 \mathrm{cM}$, $1 \mathrm{H})$. The NCBI blast results showed that the candidate gene for D15 was the homolog of the unigene AtAGD8 in Arabidopsis thaliana. AtAGD8 (ADP-ribosylation factor GTPase-activating protein domain), and its homologous gene in rice, OsAGAP, is essential for plant development and growth $[55,56]$. Similarly, the three markers at $94.9 \mathrm{cM}$ on $1 \mathrm{H}$, bpb-6911, bpb-9121 and bpb-4144, associated with relative root $\mathrm{H}^{+} \mathrm{K}^{+}$-ATPase, was co-located to the MQTL1H.4 $(102.2 \mathrm{cM}, 1 \mathrm{H})$ for drought tolerance identified by Zhang et al. [54]. MQTL1H.4 included the candidate gene ATP-dependent Clp protease ATP-binding subunit ClpX1 (CLPX). The marker bpb-3382 (66.24 cM, 1H), bpb-9005 (67.88cM, 1H) and bpb-5334 $(67.88 \mathrm{cM}, 1 \mathrm{H})$ were located at less than $3 \mathrm{cM}$ away from the MQTL D16 $(69.4 \mathrm{cM}, 1 \mathrm{H})$ on $1 \mathrm{H}$. The candidate gene ELIP2 (Early Light-Inducible protein2) in barley is related to the regulation of chlorophyll concentration in thylakoids and the redox homeostasis under photooxidative stress and water deficit conditions $[57,58]$. The marker bpb-8779 $(77.41 \mathrm{cM}, 2 \mathrm{H})$ was close to the MQTL D4, which was localized at $76.77 \mathrm{cM}$ on $2 \mathrm{H}$. There was one homolog of the candidate gene for D4 in Arabidopsis, AtPQL1 (PsbQ-like protein1). Previous studies suggested that PQL1 and PQL2 might function in the chloroplast $\mathrm{NAD}(\mathrm{P}) \mathrm{H}$ dehydrogenase (NDH) complex, which functioned in PSI cyclic electron flow [59]. Consequently, the barley ortholog of AtPQL1 may be involved in the response of plants to drought stress by influencing the photosynthetic system.

There was another homolog of the candidate gene for D4 in Arabidopsis, AtZEP (zeaxanthin epoxidase). The enzyme zeaxanthin epoxidase (ZEP) catalyzes the conversion of zeaxanthin to violaxanthin, a key reaction for ABA (abscisic acid) biosynthesis, which is important for acclimation to environmental stress, in particular drought. Drought stress can lead to an increase of ZEP in roots and to a degradation of ZEP in leaves, with similar variations in ABA [60]. Teng et al. [61] revealed that the ABA biosynthesis-related gene OsZEP in rice was up-regulated under drought stress. The marker bpb-2548 at $48.32 \mathrm{cM}$ on $3 \mathrm{H}$ was co-located to MQTL D10 $(45.77 \mathrm{cM}, 3 \mathrm{H})$. The candidate gene for D10 was the homolog of AtPLD $\alpha 1$ (Phospholipase D $\alpha 1$ ), which played roles in cellular regulation and signal transduction [62]. As to drought tolerance, AtPLD $\alpha 1$ was implicated in mediating the ABA-regulated stomatal movement and ABA-induced gene expression, as the inhibition of AtPLD 1 diminished stomatal closure induced by ABA or drought and increased water loss in Arabidopsis [63]. The marker bpb-6611 $(60.55 \mathrm{cM}, 4 \mathrm{H})$ was located similarly to MQTL D14 at $57.34 \mathrm{cM}$ on $4 \mathrm{H}$. The candidate homolog gene, AtPCK1 (phosphoenolpyruvate carboxykinase), is specifically expressed in guard cells and trichomes of the leaf in Arabidopsis. Previous studies showed that $p c k 1$ mutant plants have increased stomatal conductance and reduced drought tolerance, indicating that AtPCK1 was also involved in stomatal movement under drought stress [64].

\section{Materials and Methods}

\subsection{Plant Materials}

A total of 166 Tibetan wild barley accessions, sourced from the barley germplasm collection at Huazhong Agricultural University (Wuhan, China) were used. The hydroponic and pot experiments were conducted on Zijingang Campus, Zhejiang University, Hangzhou, China, in 2015 and both had complete randomized block designs with three replicates.

\subsection{Hydroponic Experiment}

In order to determine the traits related with roots, without damaging the root system, the hydroponic experiment was conducted. The traits of leaves from the hydroponic system can also be the validation of the following pot experiment. Seeds were surface sterilized in $2 \% \mathrm{H}_{2} \mathrm{O}_{2}$ for $30 \mathrm{~min}$, rinsed in distilled water and soaked for $3 \mathrm{~h}$ at $20^{\circ} \mathrm{C}$ in the dark, and then germinated on moist filter paper in an incubator with a $20^{\circ} \mathrm{C} / 14{ }^{\circ} \mathrm{C}$ day / night temperature regime. Ten-day-old uniform seedlings were transplanted 
into $45 \mathrm{~L}$ containers covered with a polystyrol plate with 48 evenly spaced holes (two plants per hole). The containers were placed in a greenhouse which had the same conditions with the climate outside, except for a canopy to keep the rain off, and were filled with $40 \mathrm{~L}$ of basal nutrient solution (BNS) as described in $\mathrm{Wu}$ et al. [51]. The nutrient solution was continuously aerated with pumps and renewed once a week. The $\mathrm{pH}$ of the BNS was regulated to 5.8-6.0 with $\mathrm{NaOH}$ or $\mathrm{HCl}$. On the 7th day after transplanting, two treatments were imposed on the plants: (1) control-the roots of plants were kept in the nutrient solution throughout the experiment; (2) drought stress-the plants were raised so that their roots were exposed to air for $6 \mathrm{~h}(9 \mathrm{am}-3 \mathrm{pm})$ daily for 7 days [65]. Compared with the polyethylene-glycol (PEG) or other osmotics simulated drought stress, the method in this study can avoid the influence of osmotics on the root traits. After 7 days of treatment, the shoots and roots were assessed and sampled separately. After measuring shoot height, root length and fresh weight, the topmost fully expanded leaves were sampled and stored at $-80^{\circ} \mathrm{C}$. Then, the shoots and washed roots were oven-dried for $72 \mathrm{~h}$ at $70{ }^{\circ} \mathrm{C}$ to determine their dry weights.

\subsection{Pot Experiment}

On the 7th day after watering the air-dried soil in $45 \mathrm{~L}$ containers with BNS, seeds were sown in soil from the field experimental station of Zijingang campus. One week after emergence, six uniform seedlings were retained in each pot. At the two-leaf stage, two treatments were applied: (1) control-the soil in the pots was kept moist [soil moisture content (SMC) of $35 \pm 5 \%$ ] throughout the experiment; (2) drought stress-stop watering plants for 30 days until the SMC reduced to $4 \%$. The soil moisture content was measured using an HH2 Moisture Meter (Delta-T Devices, Cambridge, UK) every second day. The topmost fully expanded leaves of two seedlings and the shoots of another two seedlings were sampled under both control and drought stress of $4 \%$ SMC. For drought stress, the two remaining seedlings were treated repeatly with the cycle of drought ( $\%$ SMC) and recovery (35 $\pm 5 \%$ SMC) until the maturation stage, while under control condition, plants were well-watered until harvest. The ears from the last developing node (top node) were harvested and the awn, internode, ear lengths, and grain weight were measured.

\subsection{Determination of $\mathrm{H}^{+} \mathrm{K}^{+}$-ATPase Activity}

The $0.3 \mathrm{~g}$ topmost fully-expanded leaves sampled from the hydroponic experiment were ground with $50 \mathrm{mM}$ Tris- $\mathrm{HCl}(\mathrm{pH}=7.4)$. The activity of $\mathrm{H}^{+} \mathrm{K}^{+}$-ATPase was determined using an activity assay kit (Jiancheng Bio Co., Nanjing, China) according to the manufacturer's instructions.

\subsection{Determination of Antioxidant Enzyme Activity, and Malondialdehyde (MDA) and Soluble Protein Contents}

The $0.3 \mathrm{~g}$ samples of topmost fully-expanded leaves were collected from control and treatment plants from the pot experiment 30 days after the commencement of the drought treatment. The tissue samples were homogenized in $8 \mathrm{~mL}$ of $50 \mathrm{mM}$ phosphate buffer (PBS, $\mathrm{pH} 7.8$ ), then centrifuged at 10,000 $\mathrm{g}$ and $4{ }^{\circ} \mathrm{C}$ for $15 \mathrm{~min}$, then the supernatants were used for measurement. MDA content, and catalase (CAT, EC 1.11.1.6) and peroxidase (POD, EC 1.11.1.7) activities were then determined according to Zhang [66]. The soluble protein content was estimated by the Coomassie brilliant blue staining method [67].

\subsection{Determination of $\mathrm{K}^{+}$Concentration}

Dried shoots and roots from the two experiments were weighed and ashed at $500{ }^{\circ} \mathrm{C}$ for $12 \mathrm{~h}$. The ash was digested with $5 \mathrm{~mL} \mathrm{30 \%} \mathrm{HNO}_{3}$, and then diluted with $5 \mathrm{~mL}$ deionized water. The $\mathrm{K}^{+}$ concentrations in the digests were then determined using flame atomic absorption spectrometry (Model AA-6300, Shimadzu, KyotoJapan). 


\subsection{Population Structure and Linkage Disequilibrium (LD)}

Genetic diversity was analyzed in the 166 wild barley accessions using 777 DArT markers [68] with only a minor allele frequency $>0.03$. The genetic polymorphism, which was determined using the 777 DArT markers, was used to assess any population structure using the STRUCTURE program (v. 2.3.3, http://pritch.bsd.uchicago.edu/structure.html, accessed on 14th October 2016) [69] in an admixture model, setting clusters $(k)$ from 1 to 15 and performing ten independent runs of 100,000 Markov Chain Monte Carlo iterations. The largest value of statistic $\Delta \mathrm{k}$ indicated the number of clusters (k) [70].

The linkage disequilibrium (LD) of the seven chromosomes was estimated using the 777 DArT markers by TASSEL software (v. 3.0, Buckler lab, New York, NY, USA, http:/ / www.maizegenetics. net) [71]. For each chromosome, the genetic distances between pairs of alleles were regressed against the squared values allele frequency correlations and LD decay curves were fitted and plotted using Origin Pro (v. 8.0, Origin Lab Corporation, Wellesley Hills, Wellesley, MA, USA).

\subsection{Genome-Wide (GWA) Association Analysis}

Association analysis between the 777 DArT markers and phenotypes of the wild barley accessions under drought treatment was performed using TASSEL v. 3.0. The Q matrix, estimating group membership coefficients for each accession, was extracted from STRUCTURE $(k=3)$ to correct for population structure in the association mapping. The kinship, pair-wise relationship matrix, was estimated using SPAGeDi [72] and was used as a cofactor in the regression model. Therefore, the GWA analysis was performed using a mixed linear model, considering both the $\mathrm{Q}$ matrix and kinship as cofactors. The Benjamini-Hochberg false discovery method was used to determine if a locus was associated with a trait. Locus with $p \leq 0.001$ was considered to be associated with a particular trait.

\subsection{Statistical Analysis}

Data presented are the average of three independent replicates. Relative values were calculated as the ratio of values under drought stress to those in the control conditions. Correlation analyses were performed to find association among phenotypic traits. Analysis of variance (ANOVA) was performed to determine differences in morphological and physiological traits using Duncan's Multiple Range tests (DMRT) at $p<0.05$ and $p<0.01$. These analyses were performed using SPSS (v.16.0, Hearne Software, IBM, Stanford, CA, USA).

\section{Conclusions}

In conclusion, there were large genotypic variations among Tibetan wild barley accessions for drought tolerance-related traits. Genome-wide association analysis detected 91 QTL and 31 putative candidate genes for further studies on gene discovery and functional analysis and marker-assistant breeding. However, confirmation studies are required to assess the allele effects more precisely and develop stable drought-tolerant barley varieties through genetic transformation and association studies.

Supplementary Materials: Supplementary materials can be found at http:/ / www.mdpi.com/1422-0067/20/3/ $791 /$ s1.

Author Contributions: Conceptualization, F.W. and M.Z.; Methodology, F.W., M.Z. and Z.-H.C.; Formal analysis, M.Z., F.W. and Z.-H.C.; Investigation, M.Z., M.-M.F., C.-W.Q. and F.C.; Resources, F.W. and G.Z.; Writing-original draft preparation, M.Z., F.W. and Z.-H.C.; Writing-review and editing, M.Z., F.W., G.Z. and Z.-H.C.; Supervision, F.W.; Project administration, F.W.

Funding: This research was funded by National Natural Science Foundation of China (grant number 31620103912, 31171488), and the Key Research Foundation of Science and Technology Department of Zhejiang Province of China (grant number 2016C02050-9-7).

Conflicts of Interest: The authors declare no conflict of interest. 


\section{References}

1. Cattivelli, L.; Rizza, F.; Badeck, F.W.; Mazzucotelli, E.; Mastrangelo, A.M.; Francia, E.; Mare, C.; Tondelli, A.; Stanca, A.M. Drought tolerance improvement in crop plants: An integrated view from breeding to genomics. Field Crops Res. 2008, 105, 1-14. [CrossRef]

2. Hu, H.H.; Xiong, L.Z. Genetic Engineering and Breeding of Drought-Resistant Crops. Annu. Rev. Plant Biol. 2014, 65, 715-741. [CrossRef] [PubMed]

3. Zhang, M.; Jin, Z.Q.; Zhao, J.; Zhang, G.P.; Wu, F.B. Physiological and biochemical responses to drought stress in cultivated and Tibetan wild barley. Plant Growth Regul. 2015, 75, 567-574. [CrossRef]

4. Xue, D.W.; Zhang, X.Q.; Lu, X.L.; Chen, G.; Chen, Z.H. Molecular and Evolutionary Mechanisms of Cuticular Wax for Plant Drought Tolerance. Front. Plant Sci. 2017, 8, 621. [CrossRef] [PubMed]

5. Chen, Z.H.; Chen, G.; Dai, F.; Wang, Y.Z.; Hills, A.; Ruan, Y.L.; Zhang, G.P.; Franks, P.J.; Nevo, E.; Blatt, M.R. Molecular Evolution of Grass Stomata. Trends Plant Sci. 2017, 22, 124-139. [CrossRef] [PubMed]

6. Rogers, E.D.; Benfey, P.N. Regulation of plant root system architecture: Implications for crop advancement. Curr. Opin. Biotechnol. 2015, 32, 93-98. [CrossRef] [PubMed]

7. Noctor, G.; Mhamdi, A.; Foyer, C.H. The Roles of Reactive Oxygen Metabolism in Drought: Not So Cut and Dried. Plant Physiol. 2014, 164, 1636-1648. [CrossRef]

8. Rampino, P.; Pataleo, S.; Gerardi, C.; Mita, G.; Perrotta, C. Drought stress response in wheat: Physiological and molecular analysis of resistant and sensitive genotypes. Plant Cell Environ. 2006, 29, $2143-2152$. [CrossRef]

9. Ellis, R.P.; Forster, B.P.; Robinson, D.; Handley, L.L.; Gordon, D.C.; Russell, J.R.; Powell, W. Wild barley: A source of genes for crop improvement in the 21st century? J. Exp. Bot. 2000, 51, 9-17. [CrossRef]

10. He, X.Y.; Zeng, J.B.; Cao, F.B.; Ahmed, I.M.; Zhang, G.; Vincze, E.; Wu, F.B. HvEXPB7, a novel $\beta$-expansin gene revealed by the root hair transcriptome of Tibetan wild barley, improves root hair growth under drought stress. J. Exp. Bot. 2015, 66, 7405-7419. [CrossRef]

11. Ahmed, I.M.; Nadira, U.A.; Bibi, N.; Cao, F.; He, X.; Zhang, G.; Wu, F.B. Secondary metabolism and antioxidants are involved in the tolerance to drought and salinity, separately and combined, in Tibetan wild barley. Environ. Exp. Bot. 2015, 111, 1-12. [CrossRef]

12. Zhang, M.; Mao, W.H.; Zhang, G.P.; Wu, F.B. Development and Characterization of Polymorphic EST-SSR and Genomic SSR Markers for Tibetan Annual Wild Barley. PLoS ONE 2014, 9, e94881. [CrossRef] [PubMed]

13. Gawenda, I.; Thorwarth, P.; Guenther, T.; Ordon, F.; Schmid, K.J. Genome-wide association studies in elite varieties of German winter barley using single-marker and haplotype-based methods. Plant Breed. 2015, 134, 28-39. [CrossRef]

14. Wang, Q.X.; Zhao, H.; Jiang, J.P.; Xu, J.Y.; Xie, W.B.; Fu, X.K.; Liu, C.; He, Y.Q.; Wang, G.W. Genetic Architecture of Natural Variation in Rice Nonphotochemical Quenching Capacity Revealed by Genome-Wide Association Study. Front. Plant Sci. 2017, 8, 1773. [CrossRef] [PubMed]

15. Hu, G.H.; Li, Z.; Lu, Y.C.; Li, C.X.; Gong, S.C.; Yan, S.Q.; Li, G.L.; Wang, M.Q.; Ren, H.L.; Guan, H.T.; et al. Genome-wide association study Identified multiple Genetic Loci on Chilling Resistance During Germination in Maize. Sci. Rep. 2017, 7, 10840. [CrossRef] [PubMed]

16. Kadam, S.; Singh, K.; Shukla, S.; Goel, S.; Vikram, P.; Pawar, V.; Gaikwad, K.; Khanna-Chopra, R.; Singh, N. Genomic associations for drought tolerance on the short arm of wheat chromosome 4B. Funct. Integr. Genomic. 2012, 12, 447-464. [CrossRef] [PubMed]

17. Varshney, R.K.; Paulo, M.J.; Grando, S.; van Eeuwijk, F.A.; Keizer, L.C.P.; Guo, P.; Ceccarelli, S.; Kilian, A.; Baum, M.; Graner, A. Genome wide association analyses for drought tolerance related traits in barley (Hordeum vulgare L.). Field Crops Res. 2012, 126, 171-180. [CrossRef]

18. Wang, R.; Leng, Y.Q.; Ali, S.; Wang, M.N.; Zhong, S.B. Genome-wide association mapping of spot blotch resistance to three different pathotypes of Cochliobolus sativus in the USDA barley core collection. Mol. Breed. 2017, 37, 44. [CrossRef]

19. Li, W.T.; Liu, C.J.; Liu, Y.X.; Pu, Z.E.; Dai, S.F.; Wang, J.R.; Lan, X.J.; Zheng, Y.L.; Wei, Y.M. Meta-analysis of QTL associated with tolerance to abiotic stresses in barley. Euphytica 2013, 189, 31-49. [CrossRef]

20. Honsdorf, N.; March, T.J.; Hecht, A.; Eglinton, J.; Pillen, K. Evaluation of juvenile drought stress tolerance and genotyping by sequencing with wild barley introgression lines. Mol. Breed. 2014, 34, 1475-1495. [CrossRef] 
21. Hu, X.; Zuo, J.; Wang, J.; Liu, L.; Sun, G.; Li, C.; Ren, X.; Sun, D. Multi-Locus Genome-Wide Association Studies for 14 Main Agronomic Traits in Barley. Front. Plant Sci. 2018, 9, 1683. [CrossRef] [PubMed]

22. Jabbari, M.; Fakheri, B.A.; Aghnoum, R.; Mahdi Nezhad, N.; Ataei, R. GWAS analysis in spring barley (Hordeum vulgare L.) for morphological traits exposed to drought. PLoS ONE 2018, 13, e0204952. [CrossRef] [PubMed]

23. Zhao, J.; Sun, H.Y.; Dai, H.X.; Zhang, G.P.; Wu, F.B. Difference in response to drought stress among Tibet wild barley genotypes. Euphytica 2010, 172, 395-403. [CrossRef]

24. Hoad, S.P.; Russell, G.; Lucas, M.E.; Bingham, I.J. The management of wheat, barley, and oat root systems. Adv. Agron. 2001, 74, 193-246.

25. Zhan, A.; Schneider, H.; Lynch, J.P. Reduced Lateral Root Branching Density Improves Drought Tolerance in Maize. Plant Physiol. 2015, 168, 1603-1615. [CrossRef] [PubMed]

26. Lambers, H.; Atkin, O.K.; Millenaar, F.F. Respiratory patterns in roots in relation to their functioning. In Plant Roots; Waisel, Y., Eshel, A., Kafkafi, U., Eds.; Marcel Dekker: New York, NY, USA, 2002; pp. 521-552.

27. Sehgal, A.; Sita, K.; Siddique, K.H.M.; Kumar, R.; Bhogireddy, S.; Varshney, R.K.; HanumanthaRao, B.; Nair, R.M.; Prasad, P.V.V.; Nayyar, H. Drought or/and Heat-Stress Effects on Seed Filling in Food Crops: Impacts on Functional Biochemistry, Seed Yields, and Nutritional Quality. Front. Plant Sci. 2018, 9, 1705. [CrossRef] [PubMed]

28. Duffus, C.M.; Cochrane, M.P. Formation of the barley grain-morphology, physiology, and biochemistry. In Barley: Chemistry and technology; MacGregor, A.W., Bhatty, R.S., Eds.; American Association of Cereal Chemists: St. Paul, MN, USA, 1993; pp. 31-72.

29. Abebe, T.; Wise, R.P.; Skadsen, R.W. Comparative Transcriptional Profiling Established the Awn as the Major Photosynthetic Organ of the Barley Spike While the Lemma and the Palea Primarily Protect the Seed. Plant Genome 2009, 2, 247-259. [CrossRef]

30. Araus, J.L.; Brown, H.R.; Febrero, A.; Bort, J.; Serret, M.D. Ear photosynthesis, carbon isotope discrimination and the contribution of respiratory $\mathrm{CO}_{2}$ to differences in grain mass in durum-wheat. Plant Cell Environ. 1993, 16, 383-392. [CrossRef]

31. Tambussi, E.A.; Bort, J.; Jose Guiamet, J.; Nogues, S.; Luis Araus, J. The photosynthetic role of ears in C(3) cereals: Metabolism, water use efficiency and contribution to grain yield. Crit. Rev. Plant Sci. 2007, 26, 1-16. [CrossRef]

32. Hein, J.A.; Sherrard, M.E.; Manfredi, K.P.; Abebe, T. The fifth leaf and spike organs of barley (Hordeum vulgare L.) display different physiological and metabolic responses to drought stress. BMC Plant Biol. 2016, 16. [CrossRef]

33. Wang, Z.; Gu, Y.J.; Gao, Y.Z. Structure and photosynthetic characteristics of awns of wheat and barley. Acta Bot. Sin. 1993, 35, 921-928.

34. Palmgren, M.G. Plant plasma membrane $\mathrm{H}^{+}$-ATPases: Powerhouses for nutrient uptake. Annu. Rev. Plant Physiol. Plant Mol. Biol. 2001, 52, 817-845. [CrossRef] [PubMed]

35. Briskin, D.P. The plasma-membrane $\mathrm{H}^{+}$-ATPase of higher-plant cells-biochemistry and transport function. Biochim. Biophys. Acta 1990, 1019, 95-109. [CrossRef]

36. Gong, D.S.; Xiong, Y.C.; Ma, B.L.; Wang, T.M.; Ge, J.P.; Qin, X.L.; Li, P.F.; Kong, H.Y.; Li, Z.Z.; Li, F.M. Early activation of plasma membrane $\mathrm{H}^{+}$-ATPase and its relation to drought adaptation in two contrasting oat (Avena sativa L.) genotypes. Environ. Exp. Bot. 2010, 69, 1-8. [CrossRef]

37. Cai, S.G.; Chen, G.; Wang, Y.Y.; Huang, Y.Q.; Marchant, D.B.; Wang, Y.Z.; Yang, Q.; Dai, F.; Hills, A.; Franks, P.J.; et al. Evolutionary Conservation of ABA Signaling for Stomatal Closure. Plant Physiol. 2017, 174, 732-747. [CrossRef] [PubMed]

38. Gong, H.J.; Chen, K.M.; Chen, G.C.; Wang, S.M.; Zhang, C.L. Drought stress stimulates p-nitrophenyl phosphate hydrolysis rate of the plasma membrane $\mathrm{H}^{+}$-ATPase from wheat leaves. Plant Growth Regul. 2003, 40, 139-145. [CrossRef]

39. Ahmed, I.M.; Nadira, U.A.; Qiu, C.W.; Cao, F.B.; Zhang, G.; Holford, P.; Wu, F.B. Tolerance to Drought, Low $\mathrm{pH}$ and $\mathrm{Al}$ Combined Stress in Tibetan Wild Barley Is Associated with Improvement of ATPase and Modulation of Antioxidant Defense System. Int. J. Mol. Sci. 2018, 19, 3553. [CrossRef]

40. Lebaudy, A.; Very, A.-A.; Sentenac, H. $\mathrm{K}^{+}$channel activity in plants: Genes, regulations and functions. FEBS Lett. 2007, 581, 2357-2366. [CrossRef] 
41. Chen, Z.H.; Wang, Y.Z.; Wang, J.W.; Babla, M.; Zhao, C.C.; Garcia-Mata, C.; Sani, E.; Differ, C.; Mak, M.; Hills, A.; et al. Nitrate reductase mutation alters potassium nutrition as well as nitric oxide-mediated control of guard cell ion channels in Arabidopsis. New Phytol. 2016, 209, 1456-1469. [CrossRef]

42. Shabala, S. Signalling by potassium: Another second messenger to add to the list? J. Exp. Bot. 2017, 68, 4003-4007. [CrossRef] [PubMed]

43. Benlloch-Gonzalez, M.; Arquero, O.; Fournier, J.M.; Barranco, D.; Benlloch, M. K ${ }^{+}$starvation inhibits water-stress-induced stomatal closure. J Plant Physiol 2008, 165, 623-630. [CrossRef] [PubMed]

44. Mian, A.; Oomen, R.J.F.J.; Isayenkov, S.; Sentenac, H.; Maathuis, F.J.M.; Very, A.-A. Over-expression of an $\mathrm{Na}^{+}$- and $\mathrm{K}^{+}$-permeable HKT transporter in barley improves salt tolerance. Plant J. 2011, 68, 468-479. [CrossRef] [PubMed]

45. Liu, X.H.; Cai, S.G.; Wang, G.; Wang, F.F.; Dong, F.B.; Mak, M.; Holford, P.; Ji, J.; Salih, A.; Zhou, M.X.; et al. Halophytic NHXs confer salt tolerance by altering cytosolic and vacuolar $\mathrm{K}^{+}$and $\mathrm{Na}^{+}$in Arabidopsis root cell. Plant Growth Regul. 2017, 82, 333-351. [CrossRef]

46. Wang, F.F.; Chen, Z.H.; Liu, X.H.; Colmer, T.D.; Zhou, M.X.; Shabala, S. Tissue-specific root ion profiling reveals essential roles of the CAX and ACA calcium transport systems in response to hypoxia in Arabidopsis. J. Exp. Bot. 2016, 67, 3747-3762. [CrossRef] [PubMed]

47. Wang, F.F.; Chen, Z.H.; Shabala, S. Hypoxia Sensing in Plants: On a Quest for Ion Channels as Putative Oxygen Sensors. Plant Cell Physiol. 2017, 58, 1126-1142. [CrossRef] [PubMed]

48. Gargallo-Garriga, A.; Sardans, J.; Perez-Trujillo, M.; Oravec, M.; Urban, O.; Jentsch, A.; Kreyling, J.; Beierkuhnlein, C.; Parella, T.; Penuelas, J. Warming differentially influences the effects of drought on stoichiometry and metabolomics in shoots and roots. New Phytol. 2015, 207, 591-603. [CrossRef]

49. Demidchik, V.; Cuin, T.A.; Svistunenko, D.; Smith, S.J.; Miller, A.J.; Shabala, S.; Sokolik, A.; Yurin, V. Arabidopsis root $\mathrm{K}^{+}$-efflux conductance activated by hydroxyl radicals: Single-channel properties, genetic basis and involvement in stress-induced cell death. J. Cell Sci. 2010, 123, 1468-1479. [CrossRef]

50. Demidchik, V. Mechanisms and physiological roles of $\mathrm{K}^{+}$efflux from root cells. J Plant Physiol 2014, 171, 696-707. [CrossRef]

51. Wu, F.B.; Zhang, G.P.; Dominy, P. Four barley genotypes respond differently to cadmium: Lipid peroxidation and activities of antioxidant capacity. Environ. Exp. Bot. 2003, 50, 67-78. [CrossRef]

52. Ranney, T.G.; Bassuk, N.L.; Whitlow, T.H. Osmotic adjustment and solute constituents in leaves and roots of water-stressed cherry (prunus) trees. J. Am. Soc. Hort. Sci. 1991, 116, 684-688. [CrossRef]

53. Sharbel, T.F.; Haubold, B.; Mitchell-Olds, T. Genetic isolation by distance in Arabidopsis thaliana: Biogeography and postglacial colonization of Europe. Mol. Ecol. 2000, 9, 2109-2118. [CrossRef] [PubMed]

54. Zhang, X.C.; Shabala, S.; Koutoulis, A.; Shabala, L.; Zhou, M.X. Meta-analysis of major QTL for abiotic stress tolerance in barley and implications for barley breeding. Planta 2017, 245, 283-295. [CrossRef] [PubMed]

55. Min, M.K.; Jang, M.; Lee, M.; Lee, J.; Song, K.; Lee, Y.; Choi, K.Y.; Robinson, D.G.; Hwang, I. Recruitment of Arf1-GDP to Golgi by Glo3p-Type ArfGAPs Is Crucial for Golgi Maintenance and Plant Growth. Plant. Physiol. 2013, 161, 676-691. [CrossRef] [PubMed]

56. Zhuang, X.; Xu, Y.; Chong, K.; Lan, L.; Xue, Y.; Xu, Z. OsAGAP, an ARF-GAP from rice, regulates root development mediated by auxin in Arabidopsis. Plant. Cell Environ. 2005, 28, 147-156. [CrossRef] [PubMed]

57. Osipenkova, O.V.; Ermokhina, O.V.; Belkina, G.G.; Oleskina, Y.P.; Fattakhov, S.G.; Yurina, N.P. Effect of Melaphene on Expression of Elip1 and Elip2 Genes Encoding Chloroplast Light-Induced Stress Proteins in Barley. Appl. Biochem. Microbiol. 2008, 44, 635-641. [CrossRef]

58. Danilova, M.N.; Kudryakova, N.V.; Voronin, P.Y.; Oelmueller, R.; Kusnetsov, V.V.; Kulaeva, O.N. Membrane receptors of cytokinin and their regulatory role in Arabidopsis thaliana plant response to photooxidative stress under conditions of water deficit. Russ. J. Plant. Physl. 2014, 61, 434-442. [CrossRef]

59. Yabuta, S.; Ifuku, K.; Takabayashi, A.; Ishihara, S.; Ido, K.; Ishikawa, N.; Endo, T.; Sato, F. Three PsbQ-Like Proteins are Required for the Function of the Chloroplast NAD $(\mathrm{P}) \mathrm{H}$ Dehydrogenase Complex in Arabidopsis. Plant. Cell Physiol. 2010, 51, 866-876. [CrossRef] [PubMed]

60. Schwarz, N.; Armbruster, U.; Iven, T.; Brueckle, L.; Melzer, M.; Feussner, I.; Jahns, P. Tissue-Specific Accumulation and Regulation of Zeaxanthin Epoxidase in Arabidopsis Reflect the Multiple Functions of the Enzyme in Plastids. Plant. Cell Physiol. 2015, 56, 346-357. [CrossRef] [PubMed] 
61. Teng, K.Q.; Li, J.Z.; Liu, L.; Han, Y.C.; Du, Y.X.; Zhang, J.; Sun, H.Z.; Zhao, Q.Z. Exogenous ABA induces drought tolerance in upland rice: The role of chloroplast and ABA biosynthesis-related gene expression on photosystem II during PEG stress. Acta Physiol. Plant. 2014, 36, 2219-2227. [CrossRef]

62. Zhao, J.; Wang, X.M. Arabidopsis phospholipase D alpha 1 interacts with the heterotrimeric G-protein alpha-subunit through a motif analogous to the DRY motif in G-protein-coupled receptors. J. Biol. Chem. 2004, 279, 1794-1800. [CrossRef] [PubMed]

63. Zhang, W.H.; Qin, C.B.; Zhao, J.; Wang, X.M. Phospholipase D alpha 1-derived phosphatidic acid interacts with ABI1 phosphatase 2C and regulates abscisic acid signaling. Proc. Natl. Acad. Sci. USA 2004, 101, 9508-9513. [CrossRef] [PubMed]

64. Penfield, S.; Clements, S.; Bailey, K.J.; Gilday, A.D.; Leegood, R.C.; Gray, J.E.; Graham, I.A. Expression and manipulation of PHOSPHOENOLPYRUVATE CARBOXYKINASE 1 identifies a role for malate metabolism in stomatal closure. Plant J. 2012, 69, 679-688. [CrossRef] [PubMed]

65. Robinson, D.; Handley, L.L.; Scrimgeour, C.M.; Gordon, D.C.; Forster, B.P.; Ellis, R.P. Using stable isotope natural abundances (delta N-15 and delta C-13) to integrate the stress responses of wild barley (Hordeum spontaneum C. Koch.) genotypes. J. Exp. Bot. 2000, 51, 41-50. [PubMed]

66. Zhang, X.Z. The measurement and mechanism of lipid peroxidation and SOD, POD and CAT activities in biological system. In Research methodology of crop physiology; Zhang, X.Z., Ed.; Agriculture Press: Beijing, China, 1992; pp. 208-211.

67. Bradford, M.M. A rapid and sensitive method for the quantitation of microgram quantities of protein utilizing the principle of protein-dye binding. Anal. Biochem. 1976, 72, 248-254. [CrossRef]

68. Cai, S.G.; Wu, D.Z.; Jabeen, Z.; Huang, Y.Q.; Huang, Y.C.; Zhang, G.P. Genome-Wide Association Analysis of Aluminum Tolerance in Cultivated and Tibetan Wild Barley. PLoS ONE 2013, 8, e69776. [CrossRef] [PubMed]

69. Pritchard, J.K.; Stephens, M.; Donnelly, P. Inference of population structure using multilocus genotype data. Genetics 2000, 155, 945-959.

70. Evanno, G.; Regnaut, S.; Goudet, J. Detecting the number of clusters of individuals using the software STRUCTURE: A simulation study. Mol. Ecol. 2005, 14, 2611-2620. [CrossRef] [PubMed]

71. Bradbury, P.J.; Zhang, Z.W.; Kroon, D.E.; Casstevens, T.M.; Ramdoss, Y.; Buckler, E.S. TASSEL: Software for association mapping of complex traits in diverse samples. Bioinformatics 2007, 23, 2633-2635. [CrossRef] [PubMed]

72. Hardy, O.J.; Vekemans, X. SPAGEDi: A versatile computer program to analyse spatial genetic structure at the individual or population levels. Mol. Ecol. Notes 2002, 2, 618-620. [CrossRef] 